\title{
DIFFERENCES OF SALIVA LEPTIN LEVELS IN CHILDREN WITH CHRONIC KIDNEY DISEASE ON HEMODIALYSIS AND HEALTHY CHILDREN (STUDY IN CHILDREN WITH GINGIVITIS)
}

\author{
BERTHAULI ESTER NURMAIDA ${ }^{1 *}$, HERIANDI SUTADI ${ }^{1}$, SARWORINI B BUDIARDJO ${ }^{1}$, EKA LAKSMI HIDAYATI ${ }^{2}$
}

${ }^{1}$ Department of Pediatric, Faculty of Dentistry, Universitas Indonesia, Jakarta 10430, Indonesia. ${ }^{2}$ Department of Pediatric Nephrology, Dr. Cipto Mangunkusumo Hospital, Universitas Indonesia, Jakarta 10430, Indonesia. Email: Berthasir@yahoo.com

Received: 24 October 2017, Revised and Accepted: 15 December 2017

\section{ABSTRACT}

Objectives: Analyze the difference of salivary leptin in between healthy children with gingivitis and hemodialysis (HD) children with gingivitis.

Methods: A total of 20 children, ages 11-16-year-old with gingivitis, were chosen as subjects; 10 were on HD and 10 were healthy children. The level of salivary leptin was measured using the enzyme-linked immunosorbent assay method.

Results: The results showed a significant difference of salivary leptin levels between the children on HD (61,300 \pm 4151 pg/ml) and the healthy children $(57,200 \pm 3173 \mathrm{pg} / \mathrm{ml})$.

Conclusions: There is a significant difference in the salivary leptin levels in children on HD with gingivitis and healthy children with gingivitis.

Keywords: Chronic kidney disease, Hemodialysis, Gingivitis, Salivary leptin.

(C) 2018 The Authors. Published by Innovare Academic Sciences Pvt Ltd. This is an open access article under the CC BY license (http://creativecommons. org/licenses/by/4. 0/) DOI: http://dx.doi.org/10.22159/ajpcr.2018.v11i4.23726

\section{INTRODUCTION}

Chronic kidney disease (CKD) indicates that kidney damage has occurred [1-3]. In end-stage renal disease, patients require therapy in the form of hemodialysis (HD), peritoneal dialysis, and kidney transplant. Patients undergoing dialysis tend to experience a variety of dental problems such as periodontal disease [4]. Some studies suggest that there is a relationship between periodontal disease and CKD [5-8].

Periodontal disease will lead to the presence of inflammation that causes the body to produce an immune reaction against the bacteria. Previous studies revealed that CKD is an inflammatory process and the biomarkers of inflammation increase since early stages of CKD [9]. The newest leptin triggered by cytokines that influence the host's response to infection and inflammatory stimulation [10-12]. Leptin is a product of the obesity (ob) gene that plays a role in regulating body weight, energy balance, reproduction, the hematopoietic system, bone remodeling, the immune system, and the neuroendocrine function [1216]. Studies measuring leptin levels in patients with CKD have shown increased serum leptin levels with respect to decreased glomerular filtration rate [13]. Based on this, the investigators of the current study were interested in examining leptin levels in salivary gingivitis patients by comparing healthy children and patients with renal failure undergoing HD therapy.

\section{MATERIALS AND METHODS}

\section{Materials}

Subjects

This study was approved by the Ethical Committee of the Faculty of Dentistry Indonesia and Cipto Mangunkusumo Hospital. This research is an observational analytical research using a cross-sectional method. Sampling was conducted in December 2016 in Cipto Mangunkusumo Hospital, Indonesia. Total numbers of 20 children with gingivitis, 10 were undergoing HD and 10 were healthy children, were selected and subjected. Sampling of saliva was performed after parents signed informed consent.

\section{Methods}

Saliva collection and measurement of salivary leptin levels

The unstimulated saliva was taken using a plastic pipette by taking $5 \mathrm{ml}$ of saliva from under the tongue. The analysis of leptin levels was performed using human leptin enzyme-linked immunosorbent assay (ELISA) (Ultrasensitive), 22-LEPHUU-E01, Alpco.

\section{Statistical Analysis}

Data analysis to determine the difference of salivary leptin levels between children with CKD on HD and healthy children was performed using an unpaired $t$-test with a significance value of $\mathrm{p} \leq 0.05$.

\section{RESULTS}

The mean value of leptin saliva levels of children with CKD on HD $(61,300 \pm 4151 \mathrm{pg} / \mathrm{ml})$ and healthy children $(57,200 \pm 3173 \mathrm{pg} /$ $\mathrm{ml}$ ). These results show that the mean of salivary leptin in children undergoing HD is higher than the mean of healthy children. The hypothesis test using an unpaired t-test obtained $p=0.023(p \leq 0.05)$. These results indicate that there is a significant difference between salivary leptin levels of children with CKD on HD with gingivitis and healthy children with gingivitis.

\section{DISCUSSION}

Several studies have suggested that there is a relationship between periodontal disease and CKD [5-8]. The etiology of periodontal disease is multifactorial. The presence of inflammation causes the body to produce an immune reaction. The most recent leptin triggered by cytokines, such as interleukin (IL)-1 $\beta$ and tumor necrosis factor-alpha (TNF- $\alpha$ ), that have an effect on the host's response to infection [12]. For this reason, we selected gingivitis groups to indicate local inflammation in the oral cavity.

Leptin is a protein secreted by various tissues in the body $[12,13]$. Leptin plays a role in the balance of energy, inflammation, bone remodeling, and the immune system $[14,15]$. Increased leptin levels 
during infection and inflammation suggest that leptin is a part of the host's response and defense mechanism of its immune system [17]. The plasma leptin concentration in CKD patients on HD differs from that found in patients with normal renal function [18]. To date, physiologic and leptin degradation pathways in humans are still unknown $[19,20]$.

The purpose of this study was to analyze differences in salivary leptin levels between children on HD and healthy children with gingivitis. This study was conducted on healthy children and a group of patients with renal failure undergoing HD therapy who have immunologic disorders affected by systemic conditions. Study about salivary leptin levels in children with CKD undergoing end-stage HD therapy with gingivitis has not been done in Indonesia.

The design of this study was an analytic observation using a crosssectional method. This study grouped children with CKD on HD and healthy children based on leptin as a biomarker [21,22]. The advantage of this research design is its simplicity and relatively short research time, and the results also were obtained in a short time.

The study sample was obtained by non-probability sampling based on consecutive sampling of all subjects who came and fulfilled the election, and all were included in the study until the required number of subjects was met [23]. Subject selection was made through clinical examination. Based on the inclusion criteria, the subjects of this study were children on HD and healthy children who had gingivitis. At the time of the research, the study subjects were ages 11-16-year-old based on the inclusion criteria. For the children with CKD undergoing HD therapy, the gingivitis index was measured, and $5 \mathrm{ml}$ of saliva was taken. After 10 research subjects with CKD were obtained, then, a study was conducted on 10 healthy children who had the same age, sex, and gingivitis index criteria of the subjects with CKD. Matching the subjects of the study was an effort to equalize the confounding variables between the two groups [21]. Matching the subjects in this study was undertaken to obtain leptin levels from each subject by eliminating factors affecting leptin fluctuations.

A non-invasive gingival examination, Lobene modified gingival index, was used to assess the clinical picture of gingival severity while eliminating the risk of bleeding. Lobene modified gingival index was chosen because there is a modification of gingivitis measurement only using the clinical picture without probing and because the examination can be performed in a relatively short time [10,24]. Measurement of the gingival index was performed to ensure that both groups studied belong to the same gingivitis group.

This study used saliva samples because, based on the literature, leptin can be produced and stored in salivary glands. Saliva was taken while the patient was in a sitting position. The children were instructed to rinse for $1 \mathrm{~min}$, then were left for $1 \mathrm{~min}$ before saliva was collected under the tongue in hopes that saliva would be obtained directly from the major salivary glands and not contaminated. The saliva was taken with long pipettes until a $5 \mathrm{ml}$ sample was collected, and the saliva then was stored in a $15 \mathrm{ml}$ tube. Saliva samples were stored in ice-cooled containers and frozen to maintain the quality of the contents [25-27].

Plasma and salivary leptin levels are influenced by circadian rhythm variation, with the highest leptin levels at 24 and the lowest at 10 [28]. The saliva sampling process was limited between 10:30 am and $2 \mathrm{pm}$ to prevent the bias of salivary leptin results due to the body's circadian rhythm and leptin levels rising from the lowest value [18-20].

The ELISA method is used to detect and measure salivary leptin levels in a sample [18]. In this study, salivary leptin levels were measured using human leptin ELISA (ultrasensitive), 22-LEPHUU-E01, Alpco, USA [29].

Previous research has demonstrated high levels of leptin in children on $\mathrm{HD}$, but the results obtained from measuring leptin levels in the blood were examined without the homogeneity of systemic conditions or the condition of group immunity $[19,30]$. Non-invasive leptin measurements can be performed in saliva [31].

The hypothesis was tested using an unpaired t-test. Table 1 summarizes a significant difference in salivary leptin levels between children with CKD on HD with gingivitis and healthy children with gingivitis $(p=0.023)$. This condition may be caused by a unique immune regulation caused by differences in the immune capacity between children on HD and healthy children [32]. The $t$-test obtained $\mathrm{p}=0.023(\mathrm{p} \leq 0.05)$. Table 1 summarizes the average value of salivary leptin levels in children with CKD on HD as $61,300 \pm 4151 \mathrm{pg} / \mathrm{ml}$ and in healthy children as $57,200 \pm 3173 \mathrm{pg} / \mathrm{ml}$. This result shows a significantly higher level of salivary leptin in children with CKD on HD than in healthy children.

Leptin is a protein produced by various tissues of the body, with its primary source being adipose tissue and production by the placenta, $\mathrm{T}$ cells, osteoblasts, and gastric epithelium $[12,13]$. In healthy humans, leptin concentration can be affected by the size of adipose tissue mass in the body, as well as sex, fasting, and other factors $[14,33]$. In this study, homogenization of age, sex, and gingival index to eliminate confounding factors may have affected leptin levels.

In late-stage CKD patients, leptin levels were significantly higher than controls with normal renal function [34]. Leptin acts on peripheral tissue and increases the inflammatory response by stimulating the production of TNF- $\alpha$, IL-6, and IL-12 [28,35,36]. High leptin concentrations in patients with CKD may be one of the mechanisms induced in inflammatory conditions due to an impaired immune system [28,33]. Leptin affects humoral and cellular immune response; this is supported by studies that show leptin directly regulating $\mathrm{B}$ cells and $\mathrm{T}$ cells. Human leptin not only modulates the activation and proliferation of human $\mathrm{T}$ lymphocytes but also increases cytokine production. Human leptin affects the regulation of the immune system by stimulating increased production of IL-2, IFN- $\gamma$, TNF- $\alpha$, and IL-6 [28].

In this study, the leptin levels examined were salivary leptin levels. Examination of salivary leptin was used to see average leptin levels in an inflammatory state with similar levels of inflammation in the oral cavity. In this study, the inflammatory state of the oral cavity that can be seen clinically is gingivitis. From the measurement of salivary leptin levels using the ELISA method, it was found that salivary leptin levels of children with CKD on HD were higher than those of healthy children. This is consistent with the literature, which suggests that, in gingivitis, the immune response is affected by the systemic state of the individual $[11,30]$. This may be associated with a chronic inflammatory state in patients with CKD, which may be affected by various factors, including increased and decreased proinflammatory cytokines, repetitive infection, and metabolic disorders.

\section{CONCLUSION}

Based on the results of the research and discussion above, it can be concluded that there is a significant difference in salivary leptin levels between children with CKD on HD with gingivitis and healthy children with gingivitis. The mean rate of salivary leptin in children with CKD undergoing HD is higher than for healthy children.

Table 1: Mean, standard, and leptin differences among children on HD with gingivitis and healthy children with gingivitis

\begin{tabular}{llll}
\hline Group & $\mathbf{n}$ & $\begin{array}{l}\text { Average leptin } \\
\text { level } \pm \text { standard } \\
\text { intersection pg/ml }\end{array}$ & p \\
\hline Healthy children & 10 & $57,200 \pm 3173$ & $0.023^{*}$ \\
Children on hemodialysis & 10 & $61,300 \pm 4151$ & \\
Amount & 20 & & \\
\hline
\end{tabular}




\section{ACKNOWLEDGMENTS}

The publication of this manuscript is supported by Universitas Indonesia in 2017.

\section{AUTHOR CONTRIBUTIONS}

The authors thank Universitas Indonesia for the financial support and the management of Cipto Mangunkusumo Hospital for their help with locating the nephrology centers where the children were treated. This study was designed and coordinated by Heriandi Sutadi, Sarworini Bagio Budiardjo, and Eka Laksmi Hidayati as the principal investigators, provided conceptual and technical guidance for all aspects of the project. Berthauli Ester Nurmaida performed the experiment, analyzed data, and wrote the manuscript.

\section{CONFLICT OF INTEREST}

The authors declare that they have no conflict of interest.

\section{REFERENCES}

1. Cameron AC, Widmer RP. Handbook of Pediatric Dentistry. UK: Elsevier Health Sciences; 2013. p. 357-61.

2. Alatas HT, Tambunan T, Pardede S. Buku Ajar Nefrologi Anak. $2^{\text {nd }}$ ed. Jakarta: Balai Penerbit FK UI; 2001. p. 490-530.

3. Noer MS, Alatas H, Tambunan T. Kompendium Nefrologi Anak. Jakarta: Balai Penerbit IDAI; 2011. p. 215-25, 232-33, 239-40.

4. Klassen JT, Krasko BM. The dental health status of dialysis patients. J Can Dent Assoc 2002;68:34-8.

5. Abhijit V, Kshirsagar RG, Moss LL, Beck JD, Offenbacher S. Periodontal disease adversely affects the survival of patiens with endstage renal disease. Kidney Int 2009;75:746-51

6. Proctor R, Kumar N, Stein A, Moles D, Porter S. Oral and dental aspects of chronic renal failure. J Dent Res 2005;84:199-208.

7. Davidovich E, Schwarz Z, Davidovitch M, Eidelman E, Bimstein E. Oral findings and periodontal status in children, adolescents and young adults suffering from renal failure. J Clin Periodontol 2005;32:1076-82.

8. Buhlin K, Bárány P, Heimbürger O, Stenvinkel P, Gustafsson A. Oral health and pro-inflammatory status in end-stage renal disease patients. Oral Health Prev Dent 2007;5:235-44.

9. Kandalevu S, Somasundaram PC, John B, Rajendran R. Proinflammatory cytokines elicit inflammatory response in blood leukocytes of post dialytic chronic renal patients through heme oxygenase activation. Int J Pharm Pharm Sci 2014;6:111-5.

10. Newman MG, Takei H, Klokkevold PR, Carranza FA. Carranza's Clinical Periodontology. Los Angeles: Elsevier Health Sciences; 2011.

11. Bimstein HL, Karimbux N, Van Dyke TE. Periodontal and Gingival Health and Disease: Children, Adolescents and Young Adult. $1^{\text {st }}$ ed. London: Martin Dunitz Ltd.; 2001.

12. Vadvadgi VH, Saini R. An evaluation and correlation of leptin in gingival crevicular fluid and serum in health, gingivitis and periodontitis. Int $\mathrm{J}$ Exp Dent Sci 2012;2:93-7.

13. Alix PM, Guebre-Egziabher F, Soulage CO. Leptin as an uremic toxin: Deleterious role of leptin in chronic kidney disease. Biochimie 2014; 105:12-21.

14. Wauters M, Considine RV, Van Gaal LF. Human leptin: From an adipocyte hormone to an endocrine mediator. Eur J Endocrinol
2000;143:293-311.

15. Margetic S, Gazzola C, Pegg GG, Hill RA. Leptin: A review of its peripheral actions and interactions. Int $\mathrm{J}$ Obes Relat Metab Disord 2002;26:1407-33.

16. Ali SH, Al-Nuaimi AM, Al-Musawi BJ. Serum Irisin and leptin levels in obese and non-obese women with polyscystic ovary syndrome with reference to glucose homeostasis. Int J Pharm Pharm Sci 2016;8:276-83.

17. Karthikeyan BV, Pradeep AR. Gingival crevicular fluid and serum leptin: Their relationship to periodontal health and disease. J Clin Periodontol 2007;34:467-72.

18. Mohkam M. Leptin is a negative acute-phase protein in chronic hemodialysis patients. Iran J Kidney Dis 2014;8:263-4.

19. Dashti NE, Nabatchian F. Leptin and interleukin-6 in end-stage renal disease. Pak J Med Sci 2008;24:694-7.

20. Sharma K, Considine RV, Michael B, Dunn SR, Weisberg LS, Kurnik BR, et al. Plasma leptin is partly cleared by the kidney and is elevated in hemodialysis patients. Kidney Int 1997;51:1980-5.

21. Nehus E, Furth S, Warady B, Mitsnefes M. Correlates of leptin in children with chronic kidney disease. J Pediatr 2014;165:825-9.

22. Rüster C, Wolf G. Adipokines promote chronic kidney disease. Nephrol Dial Transplant 2013;28 Suppl 4:iv8-14.

23. Sastroasmoro SI. Dasar-Dasar Metodologi Penelitian Klinis. $3^{\text {rd }}$ ed. Jakarta: Sagung Seto; 2010. p. 78-109, 47-53.

24. Kidney Disease Statistics for the United States. Available from: http:// www.niddk.nih.gov/health-information/health-Statistics/Documents/ KU_Diseases_Stats_508.pdf.

25. Ratna P. Hubungan Kadar Leptin Saliva dan Tingkat Tumbuh Kembang Anak Obesitas. Thesis FKG UI 2012. p. 29.

26. Atzmaryanni E. Perbedaan Kadar Leptin Saliva dan Jumlah Koloni Streptococcus mutans Antara Anak Obesitas dan Anak Normal. Thesis FKG UI; 2014. p. 42.

27. Ardiasti CS. Perbedaan Pembentukan Biofilm Streptococcus mutans in vitro Antara Anak Obesitas dan Anak Normal. Thesis FKG UI; 2014. p. 38.

28. Riejos FP, Najib S, Martín-Romero C, Pérez-Pérez A, González-Yanes C, Sánchez-Margalet V. Role of leptin in activation of immune cells. Mediators of Inflamm 2010;2010:568343.

29. Alpco. Leptin ELISA (Ultrasensitive) for Quantitative Determination of Leptin in Serum, Plasma, Urine, Saliva, and Breast Milk. New Hampshire: Alpco; 2016. p. 2-13.

30. Ay ZY, Kırzıŏlu FY, Tonguc MO, Sütçü R, Kapucuoğlu N. The gingiva contains leptin and leptin receptor in health and disease. Odontology 2012;100:222-31.

31. Randeva HS, Karteris E, Lewandowski KC, Sailesh S, O’Hare P, Hillhouse EW, et al. Circadian rhythmicity of salivary leptin in healthy subjects. Mol Genet Metab 2003;78:229-35.

32. Cohen SD, Phillips TM, Khetpal P, Kimmel PL. Cytokine patterns and survival in haemodialysis patients. Nephrol Dial Transplant 2010;25:1239-43.

33. Randeva HS, Karteris E, Lewandowski KC, Sailesh S, O’Hare P, Hillhouse EW, et al. Circadian rhythmicity of salivary leptin in healthy subjects. Mol Genet Metab 2003;78:229-35.

34. Akchurin OM, Kaskel F. Update on inflammation in chronic kidney disease. Blood Purif 2015;39:84-92.

35. Scholze A, Tepel M. Role of leptin in reverse epidemiology in chronic kidney disease. Semin Dial 2007;20:534-8.

36. Nasrallah MP, Ziyadeh FN. Overview of the physiology and pathophysiology of leptin with special emphasis on its role in the kidney. Semin Nephrol 2013;33:54-65. 